\title{
A Cross-Country Comparison of Mathematics Teachers' Beliefs About Technology in Education
}

\author{
Neo Mothobi, Department of Science, Mathematics, and Technology Education, University of Pretoria, South Africa \\ iD https://orcid.org/0000-0002-6476-0477 \\ Linda Van Ryneveld, Comprehensive Online Education Services, University of Pretoria, South Africa \\ Marien A. Graham, Department of Science, Mathematics, and Technology Education, University of Pretoria, South Africa \\ (iD) https://orcid.org/0000-0003-4071-9864
}

\begin{abstract}
The purpose of this study was to determine how South African learners compared with their selected international counterparts according to their teachers' views. The analysis was based on predictor variables that are related to the use of computer activities in teaching and learning. These variables were extracted from the 2011 Trends in Mathematics and Science Study teachers' datasets and linked to the learners' data. The results revealed that regardless of the socio-economic status between South Africa and each of the countries, it could be claimed that some similarities can be fostered. Similarity does not imply being totally identical, but rather demonstrates which teacher responses between South Africa and each of the countries might have the same structure after the statistical analysis. The differences in teachers' beliefs between South Africa and all the countries provided vital information about the scope of possible classroom practice and teachers' inclinations to different teaching approaches.
\end{abstract}

\section{KEYWORDS}

CATPCA, Congruent Coefficient, Government Expenditure on Education, Orthogonal Rotation, Teachers' Beliefs, TIMSS, TPACK Framework

\section{INTRODUCTION}

The achievement of learners in mathematics continues to attract attention from the general public, policymakers and researchers globally (Mullis et al., 2004). Looking at the underlying importance of mathematics to educational and economic opportunities, emphasising this subject is unavoidable and of great importance. The low levels of learner performance in mathematics and science remain a serious concern for different countries worldwide (Mullis, Martin, Foy, \& Arora, 2012). Schooling systems worldwide are faced with major challenges concerning the instruction and learning of mathematics in the entire education system.

White (1987), as quoted by Watanabe (2001, p. 201), stated that policymakers and researchers could use well-performing countries as a reflection "but not as a blueprint." Watanabe (2001) argued

\section{DOI: 10.4018/IJICTE.20211001.oa13}

This article published as an Open Access article distributed under the terms of the Creative Commons Attribution License (http://creativecommons.org/licenses/by/4.0/) which permits unrestricted use, distribution, and production in any medium, provided the author of the original work and original publication source are properly credited. 
that well-performing countries could serve as a reference to other countries based on the results arising from the Trends in Mathematics and Science Study (TIMSS) international comparative studies. The most imperative attribute is for underperforming countries to learn from well-performing countries when reflecting on their own practices. The emphasis should be placed on developing intervention plans, not on replicating well-performing countries' practices. Therefore, cross-country comparative studies can unearth and spell out the similarities and variations in policy and practice and the association between these rapports and variations (Grønmo \& Onstad, 2013; Martin et al., 1997; Murphy, 2010).

\section{Context}

In this study, the emphasis was on a cross-country comparison of mathematics teachers' beliefs about integrating technology into teaching and learning. This study aimed to determine how South African learners compared with their selected international counterparts according to their mathematics teachers' viewpoints regarding their use of computer activities. The comparison was based on the teachers' self-reported views that were linked to learners' data expressed during the TIMSS 2011 study. This study's objectives included exploring teachers' views regarding their use of computers and computer software in the classroom; examining the specific computer activities used in the classroom; identifying barriers that hinder successful implementation and integration of these technologies and activities; and making suggestions and recommendations for policymakers and stakeholders to improve teaching and learning in South African schools. This study was also driven by the prevailing notion that the achievements of South African learners, who participated in the TIMSS 2011 assessment, were below average when compared to other countries.

The TIMSS 2011 results have shown that learners in the six countries analysed in this study (Norway, Sweden, Saudi Arabia, Thailand, Singapore and the United Arab Emirates) all outperformed South African learners when it comes to mathematics achievement. This study analysed the TIMSS 2011 dataset, the fifth trend measure conducted by the International Association for the Evaluation of Educational Achievement (IEA) since 1995. A study focusing on teachers' viewpoints related to classroom practices is imperative because it will reveal various countries' comparative achievement worldwide. Deductions could be made on the relationships between several factors in learning situations, such as classroom practices, resource allocation, teachers' beliefs and experiences. These connections could be used in other countries for possible argumentation in learners' performance.

\section{LITERATURE REVIEW}

Mishra and Koehler (2006) developed a conceptual framework named TPACK (technological, pedagogical, and content knowledge) by enhancing Shulman's idea of "pedagogical content knowledge" and broadened it to the phenomenon of teachers integrating digital technologies into their pedagogy. The TPACK framework consists of two forms of knowledge, namely, primary and secondary knowledge. The primary forms of knowledge encompass content, pedagogy and technology. Technological pedagogic knowledge, technological content knowledge and pedagogical content knowledge are regarded as the secondary forms of knowledge. Furthermore, at the heart of these two forms of knowledge is the TPACK. The TPACK framework envisioned a teacher capable of incorporating knowledge of technology, content and pedagogy into their teaching and learning practices (Mishra \& Koehler, 2006).

Therefore, to ensure that effective mathematics teaching is accomplished, mathematics teachers must understand and embrace the TPACK framework. This framework has the potential of deepening teachers' classroom experiences. Researchers have pointed out several factors that are the stumbling blocks concerning why the introduction of technological devices has not transformed classroom practices (Graham, 2011; Howey \& Grossman, 1989; Niess, 2005). The non-availability of customised educational subject-specific professional development courses that focus on integrating technology 
into different subject areas is regarded as one of these hindrances (Niess, 2005). Teachers' training on integrating technology as part of their classroom practice is also considered one of the hindrances impacting the use of computers in education. Furthermore, computers' underutilisation has been noticeable for some time and continues to be an international issue (Abrami, 2001; Muir-Herzig, 2004; Sutherland et al., 2004). However, policymakers and researchers are aware that the integration of technology into classroom practices brings about the relationship between classroom instructions, teachers, learners, technology and the content that has to be taught.

Many studies classified teachers' beliefs into two distinct categories: constructivism and behaviourism (Lepik \& Pipere, 2011; Mansour, 2009). It has been argued that researchers and policymakers should understand these underlying theoretical issues that underpin teachers' beliefs about the integration of technology into teaching and learning. A frequent deduction in the literature is that transforming teachers' beliefs is a complicated and mysterious process (Handal, 2003; Prawat, 1992). In addition, several exploratory studies have been carried out to determine teachers' thinking associated with how they accept the use of educational technology or fail to utilise it as part of their classroom practices (Hannafin \& Freeman, 1995; Olech, 1997). To change teachers' belief systems, they should be supported in their endeavour to integrate technology into teaching and learning. That said, it is imperative for teachers to change their belief system to embrace new practices and thus infuse educational technology into teaching and learning.

\section{Research Question}

How do South African learners compare with their selected international counterparts regarding their use of computer activities?

\section{METHOD}

In this enquiry, a quantitative methodological approach was used to address the research question to ultimately achieve the research aim and objectives (Bryman \& Bell, 2007) through secondary data analysis as empirical research design (Mouton, 2001). Quantitative research aims to be more objective than qualitative research, relying on statistical methods of analysis to produce data that can be reproduced by other researchers and generalised to other contexts (Goertzen, 2017). The quantitative approach allows for the analysis of a large amount of data at once - in this case, the TIMSS 2011 data. Indeed, quantitative research's assumptions are that facts can be objective in nature and that variables in the natural world can be measured to produce data of a numerical nature that has the virtues of objectivity and accuracy (Maree, 2016).

\section{Sampling}

It should be noted that the sampling for the teachers who completed the questionnaire was based on the participating learners (Beaton, 1996). The sample participants came from a diverse set of educational systems based on socio-economic maturity, topographical setting and population proportions. The framework employed to select all the countries that were examined in this research comprises three steps, namely TIMSS 2011 datasets, socio-economic status (2011 gross domestic product (GDP) values, 2011 GDP per capita values and government expenditure on education) and statistical analysis.

\section{Step 1: TIMSS 2011 Datasets}

The population extracted from the TIMSS 2011 study entailed 302741 schools from the 59 countries that participated. The reader is reminded that TIMSS did not directly sample teachers, but rather information about learners' data used and analysed in this study acquired from the teachers offering mathematics to the sampled classes. The teacher information is treated as a characteristic of the mathematics learners (Foy, Arora, \& Stanco, 2011). 
Table 1. Countries characteristics

\begin{tabular}{|l|l|l|l|l|}
\hline \multirow{2}{*}{ Country Name } & \multicolumn{1}{c|}{$\begin{array}{c}\text { 2011 GDP } \\
\text { (Billion US\$) }\end{array}$} & \multicolumn{1}{c|}{$\begin{array}{c}\text { 2011 GDP per capita } \\
\text { (US\$) }\end{array}$} & \multicolumn{2}{c|}{$\begin{array}{c}\text { Government expenditure on } \\
\text { education }\end{array}$} \\
\cline { 4 - 6 } & & & \% of GDP & \multicolumn{1}{c|}{ Ranking } \\
\hline Saudi Arabia & 671.20 & 23770.75 & 6 & 2 \\
\hline Sweden & 563.10 & 59593.29 & 7 & 1 \\
\hline Norway & 498.20 & 100574.99 & 7 & 1 \\
\hline South Africa & 416.40 & 8049.95 & 5 & 3 \\
\hline Thailand & 370.80 & 5491.16 & 4 & 4 \\
\hline United Arab Emirates & 350.90 & 40462.31 & 1 & 6 \\
\hline Singapore & 275.60 & 53166.68 & 3 & 5 \\
\hline
\end{tabular}

\section{Step 2: Socio-Economic Status}

Various authors indicated that when educational systems are compared worldwide, it is essential to consider the significance of the different social, economic and political contexts (Crossley \& Jarvis, 2000). Table 1 shows the characteristics of all the countries analysed in the study.

\section{GDP Values}

All the countries that participated in TIMSS 2011 were grouped according to their 2011 GDP values. The rationale for using the GDP values was that countries with rich economies might put in more financial resources to their education system than emerging countries. Furthermore, the selection was based on the assumption that learners in countries with GDP values close to that of South Africa perform well based on the TIMSS results. TIMSS results have shown that all these countries perform better than South Africa in terms of learner achievement (Mullis \& Martin, 2011; Mullis et al., 2004). The country (Saudi Arabia) with the highest GDP was at 671.2 billion US dollars, while Singapore had the lowest (275.4 billion US dollars).

\section{GDP Per Capita Values}

The researcher utilised the 2011 GDP per capita based on purchasing power parity (PPP) as another determining factor to select the countries that were compared with South Africa in this study. Table 1 shows that Norway had the highest GDP per capita (100 574.99 US dollars) while Thailand had the lowest (5 491.16 US dollars). For example, in a study conducted by Lynn and Mikk (2007), the TIMSS test scores for Grade 8 learners and GDP per capita had a correlation of 0.55 . It should be noted that the GDP per capita values of these countries differ significantly.

\section{Government Expenditure on Education}

The government expenditure on education as a percentage of GDP was used as another determining factor. The analysis included countries with government expenditure on education values close to that of South Africa, based on the TIMSS 2011 Encyclopedia statistics. Sweden and Norway had the highest percentage (7) of government expenditure on education, while the United Arab Emirates had the lowest (1), as shown in Table 1.

\section{Data Collection}

The prevalent method used to gather data from teachers during the TIMSS 2011 study was the teacher's questionnaire. The questionnaire was about mathematics teachers' beliefs on issues regarding their 
Table 2. Factor analysis results

\begin{tabular}{|c|c|c|c|}
\hline \multirow{2}{*}{ Countries } & \multirow{2}{*}{ KMO } & \multicolumn{2}{|c|}{ Bartlett's test } \\
\hline & & Chi-square & p-value \\
\hline Norway & 0.570 & 4111 & 0.00 \\
\hline Sweden & 0.731 & 4182 & 0.00 \\
\hline Saudi Arabia & 0.790 & 2709 & 0.00 \\
\hline South Africa & 0.613 & 9403 & 0.00 \\
\hline Thailand & 0.662 & 4911 & 0.00 \\
\hline Singapore & 0.723 & 9893 & 0.00 \\
\hline United Arab Emirates & 0.767 & 9550 & 0.00 \\
\hline
\end{tabular}

curriculum framework, teaching and learning approaches, professional development, and finally, their pedagogical strategies used in the classroom (Martin et al., 2012; Mullis, Martin, Foy, et al., 2012). The teachers' responses about instruction were directly linked to the learners appraised and the exact mathematics classes they were taught. A single mathematics teacher of the selected mathematics class was asked to complete a self-reported mathematics questionnaire for each participating school.

\section{Data Analysis}

In this research, various statistical procedures were utilised to process and analyse data collected from the TIMSS 2011 dataset. Factor analysis, categorical principal components analysis (CATPCA), factor rotation and congruent coefficient were performed based on all seven statements regarding the teachers' viewpoints on the use of computers, as extracted from the questionnaire.

\section{Factor Analysis}

The literature reviewed indicated that factor analysis is regularly used as a data reduction technique for scientific purposes, ranging from data reduction to hypothesis testing (Cohen \& Manion, 2007; Field, 2014). Table 2 shows the factor analysis results, including the adequacy of the sample measured using the Kaiser-Meyer-Olkin (KMO) and Bartlett's tests of sphericity.

All the teacher responses that satisfied Keiser's criterion (eigenvalues $\geq 1$ ) and had acceptable variability values $(>=0.5$ ) were retained. Based on Keiser's technique, a two-factor model (computer activities) was retained based on the questions extracted from the teachers' questionnaire. Bartlett's test confirmed that the characteristics of the correlation matrices for all the countries with higher and lower government expenditure on education than South Africa were appropriate for factor analysis (Field, 2014).

\section{CATEGORICAL PRINCIPAL COMPONENT ANALYSIS}

The teacher responses extracted from the teacher questionnaire were categorical in nature; therefore, CATPCA was used to transform the ordinal data (the teacher responses) derived from them into quantifiable data. Table 3 shows the results of the CATPCA, which includes the number of factors that were extracted using the eigenvalues and percentage of variance accounted for (PVAF).

A two-factor model approach was adopted for this question based on the factor loadings from South Africa. The PVAF of Factor 1 in this model ranges from $31.71 \%$ in Norway to $57.72 \%$ in Thailand. Furthermore, the second factor ranges between 20.02\% (Saudi Arabia) and 30.55\% (Thailand). The total variance accounted for explained by these two factors was above $50 \%$, which was acceptable 
Table 3. Categorical Principal Component Analysis results

\begin{tabular}{|l|l|l|l|l|l|}
\hline \multirow{2}{*}{ Countries } & \multicolumn{2}{l|}{ Factor 1 } & \multicolumn{2}{l}{ Factor 2 } & \multirow{2}{*}{ Total PVAF } \\
\cline { 2 - 5 } & \multicolumn{1}{|c|}{ Eigenvalue } & \multicolumn{1}{|c|}{ PVAF } & \multicolumn{1}{c|}{ Eigenvalue } & \multicolumn{1}{c|}{ PVAF } & \\
\hline Norway & 2.220 & 31.71 & 1.815 & 25.93 & $57.64 \%$ \\
\hline Sweden & 3.142 & 44.89 & 1.653 & 23.62 & $68.51 \%$ \\
\hline Saudi Arabia & 3.918 & 55.97 & 1.401 & 20.02 & $75.99 \%$ \\
\hline South Africa & 3.709 & 52.99 & 2.056 & 29.37 & $82.36 \%$ \\
\hline Thailand & 4.041 & 57.72 & 2.138 & 30.55 & $88.27 \%$ \\
\hline Singapore & 3.052 & 43.61 & 2.009 & 28.94 & $72.55 \%$ \\
\hline United Arab Emirates & 3.059 & 43.70 & 1.633 & 23.34 & $67.04 \%$ \\
\hline
\end{tabular}

for all the countries used in this study. These results demonstrate that the scale produces consistent results on each occasion.

\section{Factor Rotation}

It should be taken into cognisance that, even though factors were obtained as pronounced based on the recommended processes, they were still arbitrary. Therefore, it was important to use a factor rotation because it provides the researcher with a picture of the similarities among the items in a simpler and clearer format (Barrett, 2007). The procrustean rotation method was used to rotate the component loadings of South Africa to be similar to the component loadings of each of the six countries with lower and higher government expenditure on education.

\section{Tucker Congruent Coefficient}

The congruent coefficient analysis was performed to determine how South African teachers' beliefs compared with their international counterparts. For the purpose of this study, the Lorenzo-Seva and ten Berge (2006) cut-off point was adopted and used to determine the similarity between South Africa and the other countries.

The Tucker congruent coefficient (Lorenzo-Seva \& ten Berge, 2006) was used to estimate whether there are significant similarities between South Africa and its selected international counterparts as follows:

1) If the Tucker congruent coefficient is greater than or equal to $\mathbf{0 . 9 5}$, then it was established that there were similarities between South African learners and each of the selected countries in this study.

2) If the Tucker congruent coefficient is less than $\mathbf{0 . 9 5}$, then it was established that there were no significant similarities between South African learners and each of the selected countries in this study.

\section{FINDINGS}

The descriptive and the inferential statistics analysed in this research are outlined in the subsequent paragraphs. The descriptive statistics analysed in the study included population, biographical information, use of computers, mathematical resources and sampled schools. Furthermore, teacher characteristics were analysed using the percentages of learners that were taught by teachers who provided their personal view. 


\section{Characteristics of the Sampled Population}

Table 4 shows the number of sampled schools, the number of learners, and the gender distribution of the study population.

Table 4. Demographics variables

\begin{tabular}{|c|c|c|c|c|}
\hline \multirow[b]{2}{*}{ Countries } & \multicolumn{2}{|c|}{ Number of } & \multicolumn{2}{|c|}{ Gender } \\
\hline & Schools & Learners & Female & Male \\
\hline Norway & 134 & 3972 & $44 \%$ & $56 \%$ \\
\hline Sweden & 153 & 5816 & $54 \%$ & $46 \%$ \\
\hline Saudi Arabia & 153 & 4344 & $50 \%$ & $50 \%$ \\
\hline South Africa & 285 & 11969 & $44 \%$ & $56 \%$ \\
\hline Thailand & 172 & 6124 & $65 \%$ & $35 \%$ \\
\hline Singapore & 145 & 4286 & $60 \%$ & $40 \%$ \\
\hline United Arab Emirates & 458 & 14469 & $59 \%$ & $41 \%$ \\
\hline Average & & & $54 \%$ & $46 \%$ \\
\hline
\end{tabular}

\section{Sampled Schools}

The analysis results revealed that the number of sampled schools in $71 \%$ of the countries was higher than the TIMSS sampling strategy of 150 schools. In contrast, Norway (134) and Singapore (145) had the lowest number of sampled schools. The lowest number of schools in these two countries did not affect the analysis of data. It should be noted that the results of the TIMSS analysis are not based on the number of sampled schools but rather on the number of learners who were taught by teachers who completed the teacher questionnaire.

\section{Gender Attributes}

The results from the analysis revealed that female teachers taught $54 \%$ of the sampled mathematics learners in all seven countries analysed in this study. These results indicated a slight dominance of females in 57\% of the countries sampled in this study (Sweden, Thailand, Singapore and United Arab Emirates). In contrast, there are notable exceptions in South Africa and Norway, where male teachers taught $56 \%$ of learners in each country.

\section{Qualifications}

The percentage distribution indicating the educational qualifications of teachers are given in Table 5 .

The teachers' qualifications were looked into concerning mathematics and education mathematics as the main areas of study. The study found that the average number of the learners (71\%), in all the countries analysed in this study, were taught by teachers who studied mathematics. However, in South Africa, $80 \%$ of the learners were taught by these teachers, but this did not seemingly make a positive impact on South African learners' performance. The results revealed that $40 \%$ (average number) of the learners were taught by teachers who studied and majored in education mathematics. In South Africa, 39\% of learners were taught by teachers who studied education mathematics. 
Table 5. Qualifications

\begin{tabular}{|l|l|l|l|l|}
\hline & \multicolumn{2}{|c|}{ Mathematics } & \multicolumn{2}{c|}{ Education mathematics } \\
\hline Countries & Yes & No & Yes & No \\
\hline Norway & $51 \%$ & $49 \%$ & $11 \%$ & $89 \%$ \\
\hline Sweden & $60 \%$ & $40 \%$ & $62 \%$ & $38 \%$ \\
\hline Saudi Arabia & $60 \%$ & $40 \%$ & $66 \%$ & $34 \%$ \\
\hline South Africa & $80 \%$ & $20 \%$ & $39 \%$ & $61 \%$ \\
\hline Thailand & $80 \%$ & $20 \%$ & $17 \%$ & $83 \%$ \\
\hline Singapore & $76 \%$ & $24 \%$ & $38 \%$ & $62 \%$ \\
\hline United Arab Emirates & $91 \%$ & $9 \%$ & $46 \%$ & $54 \%$ \\
\hline Average & $71 \%$ & $29 \%$ & $40 \%$ & $60 \%$ \\
\hline
\end{tabular}

Table 6. Use of computers by teachers

\begin{tabular}{|l|l|l|l|l|l|l|}
\hline \multirow{2}{*}{ Countries } & \multicolumn{2}{c|}{ Administration } & \multicolumn{2}{c|}{ Lesson preparation } & \multicolumn{2}{c|}{ Instruction } \\
\cline { 2 - 8 } & \multicolumn{2}{|c|}{ Yes } & \multicolumn{1}{c|}{ No } & \multicolumn{1}{c|}{ Yes } & \multicolumn{1}{c|}{ No } & \multicolumn{2}{c|}{ Yes } & \multicolumn{1}{c|}{ No } \\
\hline Norway & $97 \%$ & $3 \%$ & $97 \%$ & $3 \%$ & $96 \%$ & $4 \%$ \\
\hline Sweden & $98 \%$ & $2 \%$ & $96 \%$ & $4 \%$ & $81 \%$ & $19 \%$ \\
\hline Saudi Arabia & $55 \%$ & $45 \%$ & $89 \%$ & $11 \%$ & $69 \%$ & $31 \%$ \\
\hline South Africa & $70 \%$ & $30 \%$ & $41 \%$ & $59 \%$ & $31 \%$ & $69 \%$ \\
\hline Thailand & $81 \%$ & $19 \%$ & $84 \%$ & $16 \%$ & $43 \%$ & $57 \%$ \\
\hline Singapore & $99 \%$ & $1 \%$ & $100 \%$ & $0 \%$ & $96 \%$ & $4 \%$ \\
\hline United Arab Emirates & $78 \%$ & $22 \%$ & $85 \%$ & $15 \%$ & $80 \%$ & $20 \%$ \\
\hline Average & $83 \%$ & $17 \%$ & $84 \%$ & $16 \%$ & $71 \%$ & $29 \%$ \\
\hline
\end{tabular}

Table 7. Use of computer software

\begin{tabular}{|l|l|l|l|}
\hline \multicolumn{1}{|c|}{ Countries } & \multicolumn{1}{c|}{ Basic instruction } & \multicolumn{1}{c|}{ Supplement } & \multicolumn{1}{c|}{ Not used } \\
\hline Norway & $6 \%$ & $81 \%$ & $13 \%$ \\
\hline Sweden & $3 \%$ & $48 \%$ & $49 \%$ \\
\hline Saudi Arabia & $21 \%$ & $51 \%$ & $28 \%$ \\
\hline South Africa & $6 \%$ & $19 \%$ & $75 \%$ \\
\hline Thailand & $5 \%$ & $51 \%$ & $44 \%$ \\
\hline Singapore & $10 \%$ & $82 \%$ & $8 \%$ \\
\hline United Arab Emirates & $22 \%$ & $56 \%$ & $22 \%$ \\
\hline Average & $11 \%$ & $55 \%$ & $34 \%$ \\
\hline
\end{tabular}




\section{Use of Computers by Teachers}

The percentage distribution indicating how teachers have used computers for administration, lesson preparation and instruction are given in Table 6.

The statistics revealed that learners are taught by teachers who used digital technologies such as computers for administration (83\%), lesson preparation (84\%) as well as instruction (71\%) in all the countries analysed in the study. However, South African teachers (41\%) seem to lag behind the other countries in that fewer of them used computers for lesson preparation purposes.

\section{Use of Computer Software}

The percentage distributions indicating how teachers have used computer software are given in Table 7.

The statistics revealed that $55 \%$ of learners are taught by teachers who used computer software as a supplementary resource. However, $34 \%$ of teachers from all the countries analysed in the study indicated that they had not used computer software in their classroom.

\section{INFERENTIAL STATISTICS}

Table 8 presents the questions related to the use of computers extracted from the teachers' questionnaire and analysed in this study.

Table 8. Computer activities

\begin{tabular}{|c|c|c|c|}
\hline Computer activities & Choice & Codebook & Measurement \\
\hline \multirow{4}{*}{$\begin{array}{l}\text { How much do you agree with the following statements } \\
\text { about using computers in your classroom instruction? }\end{array}$} & 1 & Agree a lot & Ordinal \\
\hline & 2 & Agree a little & Ordinal \\
\hline & 3 & Disagree a little & Ordinal \\
\hline & 4 & Disagree a lot & Ordinal \\
\hline \multirow{4}{*}{$\begin{array}{l}\text { How often do you have the learners do the following } \\
\text { computer activities during mathematics lessons? }\end{array}$} & 1 & Every or almost every day & Ordinal \\
\hline & 2 & Once or twice a week & Ordinal \\
\hline & 3 & Once or twice a month & Ordinal \\
\hline & 4 & Never or almost never & Ordinal \\
\hline
\end{tabular}

Table 9 shows the summary of the similarity results between South Africa and each of the countries analysed in this study. Congruent coefficients less than 0.95 are indicated using bold in Table 9 .

It is evident from the results that similarities were found between South African learners and their international counterparts on the use of computer activities in mathematics classrooms regarding those items that showed a congruent coefficient of more than 0.95 . In contrast, the data analysis shows that there is little similarity between the way South African teachers and their international counterparts (Norway, Sweden, Thailand, Singapore and the United Arab Emirates) reported on their feelings with regards to using computers in their teaching.

The results showed similarities between South African learners and their selected international counterparts in terms of how they used different computer activities based on their teachers' reports. Significant similarities were found in $67 \%$ of the statements between South Africa and the countries analysed in this study. The overall congruent coefficients were above the required threshold for four (out of six) countries analysed in this study, namely Sweden (0.96), Saudi Arabia (0.96), Thailand 
Table 9. Similarity values between South Africa and each of the countries

\begin{tabular}{|c|c|c|c|c|c|c|c|}
\hline \multirow{3}{*}{\multicolumn{2}{|c|}{$\begin{array}{l}\text { Variables selected from the TIMSS } 2011 \text { Teacher } \\
\text { Questionnaire } \\
\begin{array}{l}\text { Teachers' self-reporting on their use of computers in the } \\
\text { classroom }\end{array}\end{array}$}} & \multicolumn{6}{|c|}{ Countries with } \\
\hline & & \multicolumn{3}{|c|}{$\begin{array}{l}\text { Higher government } \\
\text { expenditure on education }\end{array}$} & \multicolumn{3}{|c|}{$\begin{array}{l}\text { Lower government } \\
\text { expenditure on } \\
\text { education }\end{array}$} \\
\hline & & NOR & SWE & SAU & THA & SGP & UAE \\
\hline \multicolumn{2}{|c|}{ a) Feel comfortable using computers in my teaching } & 0.64 & 0.75 & 0.99 & 0.75 & 0.86 & 0.59 \\
\hline \multicolumn{2}{|c|}{$\begin{array}{l}\text { b) I have ready access to computer support staff in my } \\
\text { school }\end{array}$} & 0.99 & 0.99 & 0.98 & 0.99 & 1.00 & 0.99 \\
\hline \multicolumn{2}{|c|}{$\begin{array}{l}\text { c) Adequate support for integrating computers in my } \\
\text { teaching activities }\end{array}$} & 0.96 & 0.99 & 0.90 & 0.97 & 0.98 & 0.99 \\
\hline \multicolumn{8}{|c|}{ Specific computer activities used in the classroom } \\
\hline \multicolumn{2}{|c|}{ a) Explore mathematical principles and concepts } & 1.00 & 0.99 & 0.96 & 1.00 & 1.00 & 0.98 \\
\hline \multicolumn{2}{|l|}{ b) Practise skills and procedures } & 0.98 & 1.00 & 0.98 & 1.00 & 1.00 & 0.99 \\
\hline \multicolumn{2}{|l|}{ c) Look up ideas and information } & 1.00 & 1.00 & 0.99 & 1.00 & 0.99 & 1.00 \\
\hline \multicolumn{2}{|l|}{ d) Process and analyse data } & 0.99 & 0.99 & 0.99 & 1.00 & 1.00 & 0.99 \\
\hline \multicolumn{2}{|l|}{ Overall congruent coefficient } & 0.94 & 0.96 & 0.96 & 0.96 & 0.97 & 0.93 \\
\hline \multirow{2}{*}{$\begin{array}{l}\text { Percentage of statements with } \\
\text { congruent coefficient }\end{array}$} & Less than $<0.95$ & $14.3 \%$ & $14.3 \%$ & $14.3 \%$ & $14.3 \%$ & $14.3 \%$ & $14.3 \%$ \\
\hline & $\begin{array}{l}\text { Greater than or equal } \\
\text { to } 0.95\end{array}$ & $85.7 \%$ & $85.7 \%$ & $85.7 \%$ & $85.7 \%$ & $85.7 \%$ & $85.7 \%$ \\
\hline
\end{tabular}

(0.96) and Singapore (0.97). In contrast, no similarities were found between South African learners and their international counterparts in Norway (0.94) and the United Arab Emirates (0.93).

\section{DISCUSSION AND CONCLUSION}

The overall consolidated teachers' results revealed significant similarities between South African learners and their selected international counterparts in Saudi Arabia, Sweden, Thailand and Singapore, who have all used different computer activities in their mathematics classrooms. This study showed that South African learners do compare with their counterparts (Saudi Arabia, Sweden, Thailand and Singapore) regarding how their teachers have used computer activities.

It is imperative for teachers to know how to use and integrate technology into teaching and learning and possess the necessary skills to do this. However, the details of the intervention should be made known to teachers in South Africa and their international counterparts. According to Bracey (1993), the introduction of computers into teaching and learning is believed to have a bearing on teachers' role as well as shifting their beliefs from a didactic to a constructivist approach. It is once again clear that South Africa lags behind when it comes to using computer software as our data shows that we hardly use it for basic instructional purposes or as a supplement to regular classroom teaching. We also have the highest number of learners who do not use computer software compared to the countries with lower government expenditure on education in the study. Therefore, it can be deduced that government expenditure on education is not the only factor influencing the use of computer activities in mathematics classrooms. 
It should be noted that the slow progress of providing schools in South Africa with appropriate interactive software for use in schools might have contributed to these patterns of usage. It can be concluded that regardless of the procurement of these digital resources, the results in this study revealed disparities regarding the impact of these technologies in the classroom instructions in South African schools. Thus, the results highlight the differences in these countries regarding the allocation and use of computers by teachers. Furthermore, the results revealed that fewer South African learners are taught by teachers using computers for teaching and learning (31\%) than the international counterparts analysed in this study.

\section{SUGGESTIONS AND RECOMMENDATIONS FOR FUTURE RESEARCH}

As all of the other countries' learners outperformed the South African learners in mathematics performance, stakeholders (the Department of Basic Education, the National Professional Teachers' Organisation of South Africa and others) should explore ways to learn from these countries' best practices in education. This can be done by sending South African educational researchers to these countries to observe their teaching practices and, upon returning to South Africa, incorporating what they have learned into South African schools' teaching practices. It is suggested that the emphasis be placed on developing intervention plans that will work within the South African context, not on replicating well-performing countries' practices.

Teachers must know how to use and integrate technology into teaching and learning and possess the necessary skills. Policymakers need to provide South African teachers with continuous professional development and training on incorporating educational technology into their mathematics classrooms effectively. In the interim, qualified information technology technicians can be appointed on a contract basis to assist South African teachers struggling with integrating educational technology into their classrooms.

One of the limitations of this study was that secondary data was used, and we were limited to the instruments used in TIMSS 2011. Therefore, it is recommended that future researchers use a qualitative approach to elaborate on the findings of this study, as qualitative data could provide a more in-depth understanding of the topic considered here. Interviews could be conducted with South African teachers to capture rich data about how they think and behave, specifically in terms of classroom practices. The hope is that this study's findings might be used to develop strategies to support educational technology integration in South African mathematics classrooms. 


\section{REFERENCES}

Abrami, P. C. (2001). Understanding and promoting complex learning using technology. Educational Research and Evaluation, 7(2-3), 113-136. doi:10.1076/edre.7.2.113.3864

Barrett, P. (2007). Structural equation modelling: Adjudging model fit. Personality and Individual Differences, 42(5), 815-824. doi:10.1016/j.paid.2006.09.018

Beaton, A. E. (1996). Mathematics Achievement in the Middle School years: IEA's Third International Mathematics and Science Study. TIMSS.

Bracey, G. (1993). New pathways: Technology's empowering influence on teaching. Electronic Learning, 12(7), 8-9.

Bryman, A., \& Bell, E. (2007). Business Research Strategies. In Business Research Methods. University Press.

Cohen, L., \& Manion, L. (2007). Research Methods in Education (6th ed.). Routlege Falmer. doi: $10.4324 / 9780203029053$

Crossley, M., \& Jarvis, P. (2000). Introduction: Continuity, challenge and change in comparative and international education. Comparative Education, 36(3), 261-265. doi:10.1080/713656614

Field, A. (2014). Discovering statistics using IBM SPSS Statistics (4th ed.). Sage Publications Inc.

Foy, P., Arora, A., \& Stanco, G. M. (2011). TIMSS 2011 User Guide for the International Database. Supplement 1: International Version of the TIMSS 2011 Background and Curriculum Questionnaires. International Association for the Evaluation of Educational Achievement.

Goertzen, M. J. (2017). Introduction to quantitative research and data. Library Technology Reports, 53(4), 12-18.

Graham, C. R. (2011). Theoretical considerations for understanding technological pedagogical content knowledge (TPACK). Computers \& Education, 57(3), 1953-1960. doi:10.1016/j.compedu.2011.04.010

Grønmo, L. S., \& Onstad, T. (2013). Ups and downs. Analyses of TIMSS data for Norway and Sweden. Akademika Publishing House.

Handal, B. (2003). Teachers' Mathematical Beliefs: A Review. The Mathematics Educator, 13(2), 47-57.

Hannafin, R. D., \& Freeman, D. J. (1995). An exploratory study of teachers' views of knowledge acquisition. Educational Technology, 35(1), 29-56.

Howey, K. R., \& Grossman, P. L. (1989). A study in contrast: Sources of pedagogical content knowledge for secondary English. Journal of Teacher Education, 40(5), 24-31. doi:10.1177/002248718904000504

Lepik, M., \& Pipere, A. (2011). Baltic-Nordic comparative study on mathematics teachers' beliefs: Designing research instrument to describe the beliefs and practices of mathematics teachers. Acta Paedagogica Vilnensia, 27, 115-123.

Lorenzo-Seva, U., \& ten Berge, J. M. F. (2006). Tucker's congruence coefficient as a meaningful index of factor similarity. Methodology: European Journal of Research Methods for the Behavioral and Social Sciences, 2(2), 57-64. doi:10.1027/1614-2241.2.2.57

Lynn, R., \& Mikk, J. (2007). National differences in intelligence and educational attainment. Intelligence, 35(2), 115-121. doi:10.1016/j.intell.2006.06.001

Mansour, N. (2009). Science teachers' beliefs and practices: Issues, implications and research agenda. International Journal of Environmental and Science Education, 4(1), 25-48.

Maree, K. (Ed.). (2016). First steps in research (2nd ed.). Van Schaik.

Martin, M. O., Mullis, I. V. S., Beaton, A. E., Gonzalez, E. J., Kelly, D. L., \& Smith, T. A. (1997). Mathematics Achievement in the Primary School years: IEA's Third International Mathematics and Science Study (TIMSS). Boston College.

Martin, M. O., Mullis, I. V. S., Foy, P., \& Stanco, G. M. (2012). TIMSS 2011 International Results in Mathematics. Boston College. 
Mishra, P., \& Koehler, M. J. (2006). Technological Pedagogical Content Knowledge: A new Framework for Teacher Knowledge. Teachers College Record, 108(6), 1017-1054. doi:10.1111/j.1467-9620.2006.00684.x

Mouton, J. (2001). How to succeed in your Master's and Doctoral studies: A South African guide and resource book. Van Schaik.

Muir-Herzig, R. G. (2004). Technology and its impact in the classroom. Computers \& Education, 42(2), 111-131. doi:10.1016/S0360-1315(03)00067-8

Mullis, I. V. S., \& Martin, M. O. (2011). Trends in Mathematics and Science Study (TIMSS). Item writing guidelines. Boston College.

Mullis, I. V. S., Martin, M. O., Foy, P., \& Arora, A. (2012). TIMSS 2011 International Results in Mathematics. Boston College.

Mullis, I. V. S., Martin, M. O., Gonzalez, E. J., \& Chrostowski, S. J. (2004). TIMSS 2003 International Mathematics. Report: Findings from IEA's Trends in International Mathematics and Science Study at the fourth and eighth grades. Boston College: TIMSS and PIRLS International Study Center, Lynch School of Education.

Murphy, S. (2010). The Pull of PISA: Uncertainty, Influence, and Ignorance. Interamerican Journal of Education for Democracy, 3(1), 28-44.

Niess, M. L. (2005). Preparing teachers to teach science and mathematics with technology: Developing a technology pedagogical content knowledge. Teaching and Teacher Education, 21(5), 509-523. doi:10.1016/j. tate.2005.03.006

Olech, C. (1997). The relationship between teachers' pedagogical beliefs and the level of instructional computer use (Doctoral dissertation). University of Central Florida.

Prawat, R. S. (1992). Teachers' beliefs about teaching and learning: A constructivist perspective. American Journal of Education, 100(3), 354-395. doi:10.1086/444021

Sutherland, R., Armstrong, V., Barnes, S., Brawn, R., Breeze, N., Gall, M., Matthewman, S., Olivero, F., Taylor, A., Triggs, P., Wishart, J., \& John, P. (2004). Transforming teaching and learning: Embedding ICT into everyday classroom practices. Journal of Computer Assisted Learning, 20(6), 413-425. doi:10.1111/j.13652729.2004.00104.x

Watanabe, T. (2001). Content and organisation of teacher's manuals: An analysis of Japanese elementary mathematics teacher's manuals. School Science and Mathematics, 101(4), 194-205. doi:10.1111/j.1949-8594.2001. tb18022.x

White, M. (1987). The Japanese educational challenge: A commitment to children. The Free Press.

Neo Mothobi recently received his PhD in CiE at the University of Pretoria, South Africa.

Linda van Ryneveld is the Head of Comprehensive Online Education Services and an Associate Professor in Computer-integrated Education at the University of Pretoria. She is also the Head of Residence at House Mopane, one of the male residences of the university. Linda holds a PhD in Computer-integrated Education from the University of Pretoria. She has published widely on topics relating to eLearning and the use of technology in teaching and learning, and has successfully supervised more than ten postgraduate students in this field to date. A further eleven PhD candidates are currently working under her supervision. Linda is often asked to act as external examiner for theses and dissertations, serves as an executive committee member on a number of associations and professional societies, and is a seasoned facilitator of workshops and seminars in her field. Linda's current research interests include all types of learning (with specific focus on mobile learning), instructional and curriculum design, open educational resources, game-based learning and gamification, as well as the academic development of university teaching staff.

Marien A. Graham is a specialist in Assessment and Quality Assurance, Nonparametric Statistics and Statistical Quality Control. She is a rated researcher with the National Research Foundation (NRF), South Africa (Y1 rating). She is an Associate Professor at the Department of Science, Mathematics and Technology Education, University of Pretoria, South Africa and co-author of Nonparametric Statistical Process Control, John Wiley \& Sons (2019). She is on the editorial advisory board of Scientific Studies and Research, Series Mathematics and Informatics, has published in numerous accredited international peer-reviewed journals and has presented her research at several national and international conferences. 